Creative Commons User License: CC BY-NC-ND

Abstracted by: EBSCOhost, Electronic Journals Service (EJS),

Google Scholar, Journal Seek, Scientific Commons,

Food and Agricultural Organization (FAO), CABI and Scopus

http://eoi.citefactor.org/10.11226/v24i4
Journal of Agricultural Extension

Vol. 24 (4) October, 2020

ISSN(e): 24086851; ISSN(Print); 1119944X

http://journal.aesonnigeria.org

http://www.ajol.info/index.php/jae

Email: editorinchief@aesonnigeria.org

\title{
Characteristics of Shea Butter Processing in Niger State, Nigeria
}

https://dx.doi.org/10.4314/jae.v24i4.6

\section{Tijani Sarafat Ayanfunke}

Department of Agricultural Extension and Rural Development, Faculty of Agriculture, University of Ibadan, Ibadan.

Email: tsarafat@yahoo.com.

Phone: 08051370802.

\section{Sanusi Mohammed Kabiru}

Nigerian Institute for Oil Palm Research (NIFOR), Date palm Sub-station, Dutse, Jigawa State, Nigeria.

Email: sanusimk2004@gmail.com.

Phone: 08033638872.

\section{Abstract}

The study examined the characteristics of Shea Butter processing and factors associated with the output in Niger states, Nigeria. Two stage sampling procedure was used to select 315 respondents. Interview schedule was used in data collection. Data collected were analysed with percentages, Chisquare, the Pearson Product Moment Coefficient (PPMC) and simple regression model at $\alpha 0.05$. The result revealed that the majority $(80.6 \%)$ of the respondents used semi-mechanised method in processing Shea butter. The average unit price of Shea butter was $\mathbf{N 4 7 6 . 0 7 K ~ p e r ~ K i l o g r a m m e , ~ w h i l e ~}$ the average income was $\mathbf{N} 439,650.37 \mathrm{~K}$ per annum. Processors had low level of accessibility to modern processing technologies (66.2\%) and more than half (64.8\%) of the processors were producing at low level. Lack of credit facilities and high cost of processing equipment were identified as severe constraint to Shea butter processing. There were significant relationship between level of education $\left(X^{2}=11.18, p \leq 0.05\right)$, level of engagement $\left(X^{2}=8.71\right.$, $p \leq 0.05)$, income $(r=0.819, p \leq 0.05)$ and accessibility to modern Shea butter processing technologies $(r=0.164, p \leq 0.05)$ with level of Shea butter processing output. The major determinants of Shea butter processing output were income, household size, unit price and accessibility to modern processing technologies. Financial institutions should provide soft loans to Shea butter processors to acquire inputs and equipment. Similarly, government agencies should provide Shea butter processing equipment to the processors to improve access to the technologies that could lead to increase Shea butter production in Niger state.

Keywords: Shea butter processing, determinants of processing output, technology accessibility and processors.

\section{Introduction}

The Shea trees is found growing naturally in the wild dry savannah belt of West and East Africa that spanned across 20 Sub-African countries (Sanusi, Adeloye and Adegebo, 2017). Incidentally, Nigeria is the largest producer of Shea nuts in the world (Food Agriculture Organisation, 2018; Akinsokeji, Tijani, Sanusi, Igene and Orifah 2017). Shea trees are found in 21 states of the federation including the FCT 
Creative Commons User License: CC BY-NC-ND

Abstracted by: EBSCOhost, Electronic Journals Service (EJS),

Google Scholar, Journal Seek, Scientific Commons,

Food and Agricultural Organization (FAO), CABI and Scopus
Journal of Agricultural Extension

Vol. 24 (4) October, 2020

ISSN(e): 24086851; ISSN(Print); 1119944X

http://journal.aesonnigeria.org

http://www.ajol.info/index.php/iae

Email: editorinchief@aesonnigeria.org

(NEPC, 2017). The country is expected to earn substantial foreign exchange from the export of Shea nuts and its derivatives because of the high demand in the international market as a result of the use of Shea butter as a substitute for Cocoa Butter Equivalent (CBE). Western Europe industries are the main market for CBE; however, the growth of the CBE market is attributed to new entrants into the market from Eastern Europe, Russia, Brazil, and Oceania (Rousseau, Denis and Wardell, 2015).

Akinsokeji, et.al, (2017) reported that Shea butter processing in the country use traditional methods that have direct influence on the quantity of butter that is eventually produced. Tijani and Sanusi (2019) also noted that Shea nuts are smuggled across the borders to neighbouring countries where the nuts are transformed into other useful products, while the level of involvement in processing activities in Nigeria is low.

Niger State is one of the leading producers of Shea butter in the country with large number of Shea trees which is considered as a potential cash crop. Hence, Niger State Commodity Export Promotion Council (NSCEPC) collaborated with Deutshe Gesellschaft Fūr internationale Zusammenarrbeit (GIZ) $\mathrm{GmbH}$, a German Cooperation mission in Nigeria that facilitated different interventions in the Shea sector, aimed at increasing Shea butter production in the state and improve the income base of the processors as well as their social well-being (Sanusi and Tijani, 2018). Thus, how this has impacted on the processors output is yet to be determined. The study investigated the characteristics of Shea butter processing in Niger State, Nigeria.

The described the characteristics of Shea butter processing in Niger State, Nigeria. The specific objectives were to:

- examine processors' level of accessibility to modern Shea butter processing technologies;

- determine the processors' level of output;

- investigate the factors associated with Shea butter processing output; and

- identify the constraints to Shea butter processing.

The study hypothesized that there is no significant association between selected socio-economic characteristics, accessibility to modern Shea butter processing technologies with level of processing output.

\section{Methodology}

The study was carried out in Niger State, Nigeria. Niger state is on longitude $6^{\circ} .55^{\prime \prime}$ East and latitude $9^{\circ} .62 " \mathrm{~N}$. The Niger state is made up of 25 local government areas (LGAs) that were divided into three senatorial districts for easy administration. The state falls into the North-central zone of the country and is known for high population 
Creative Commons User License: CC BY-NC-ND

Abstracted by: EBSCOhost, Electronic Journals Service (EJS),

Google Scholar, Journal Seek, Scientific Commons,

Food and Agricultural Organization (FAO), CABI and Scopus
Journal of Agricultural Extension

Vol. 24 (4) October, 2020

ISSN(e): 24086851; ISSN(Print); 1119944X

http://journal.aesonnigeria.org

http://www.ajol.info/index.php/jae

Email: editorinchief@aesonnigeria.org

of Shea butter processors in Nigeria. The population of the study was the Shea butter processors in Niger state. Two-stage sampling procedure was used. The first stage involved purposive selection of $35 \%$ of local government areas (LGAs) in Niger state that were known for Shea butter production and large numbers of processors, giving a total of nine (9) LGAs. The LGAs selected were Gbako, Lavun, Katcha, Bida, Kotangora, Mashegu, Borgu, Wushishi and Agwara.

The second stage involved random selection of 35 processors from the list of registered Shea butter processors in each selected LGAs to give 315 respondents for the study. Interview schedule was administered to the respondents with the aid of Niger State Agricultural Mechanisation Development Agency (NAMDA) staff working in the LGAs. The accessibility to modern processing technologies was measured on a two-point scale of accessible and inaccessible with a score of 1 and 0 respectively. The weighted mean score was used to rank the technologies in order to identify the most accessible technologies in the study area. The grand mean was also computed and used to categorise the processors into high accessibility to modern Shea butter processing technologies for values from the mean of 1.70 and above and low for values below. The Shea butter processing output was measured at interval level by weighing a unit quantity of Shea butter for sale and converting it to annual Shea butter processor output. The average Shea butter processor output of $2303.66 \mathrm{Kg}$ was used to categorise level of processors output into high for value from 2303.66 $\mathrm{Kg}$ and above and low for value below. Constraints were measured on a three-point scale of severe, mild and never with scores of 2, 1 and 0 respectively. The weighted scores were computed and used to rank the constraints based on the severity.

Regression analysis was used to ascertain the association of selected socioeconomic characteristics and level of accessibility to modern Shea butter processing technologies on Shea butter processors' output in Niger state. The linear regression model was used and the functional linear relationship is given as equations below.

$$
\begin{aligned}
& Y=f(X 1, X 2, X 3, X 4, X 5, X 6 \\
& Y=\beta_{0}+X 1+X 2+X 3+\ldots \ldots .
\end{aligned}
$$

Where $Y=$ Shea butter production, $X 1=$ household size, $X 2=$ education (formal), $X 3=$ unit price per $\mathrm{Kg}$ butter, $\mathrm{X} 4=$ income from Shea butter, $\mathrm{X} 5=$ level of engagement, $X 6=$ sources of finance and $X 7=$ accessibility to modern processing technologies and $\mathrm{Ui}=$ error.

\section{Results and Discussion}

\section{Level of Accessibility to Modern Shea Butter Processing Technologies}

Table 1 reveals that milling machine $(\bar{x}=0.9)$, crusher $(\bar{x}=0.3)$ and roaster $(\bar{x}=0.2)$ were the most accessible modern Shea butter processing technologies in Niger State. The reason for the processors identifying these technologies as the most accessible technology could possibly be that the technologies (equipment) were given to the processors by the Government and development partners like GIZ in the state as a means to boost Shea butter production in term of quality and quantity. It 
Creative Commons User License: CC BY-NC-ND

Abstracted by: EBSCOhost, Electronic Journals Service (EJS),

Google Scholar, Journal Seek, Scientific Commons,

Food and Agricultural Organization (FAO), CABI and Scopus

http://eoi.citefactor.org/10.11226/v24i4
Journal of Agricultural Extension

Vol. 24 (4) October, 2020

ISSN(e): 24086851; ISSN(Print); 1119944X

http://journal.aesonnigeria.org

http://www.ajol.info/index.php/jae

Email: editorinchief@aesonnigeria.org

could also be that the technologies can be used to reduce drudgery and produce more butter at a time.

However, the least accessible technologies in Niger State were expeller $(\bar{x}=0.0)$, vibrating screen $(\bar{x}=0.0)$ and pre-cleaner $(\bar{x}=0.0)$. The reason for this could be that the technologies (equipment) may be very expensive for the processors to acquire as individual or collectively. It could also be that the technologies (equipment) did not add any value in term of increasing the quantity of Shea butter produced because it was not effective to completely remove the Shea butter from the waste.

With Regard to the distribution of the processors based on the level of accessibility to modern Shea butter processing technologies, the data reveals that the level of accessibility to modern Shea butter processing technologies was low among the processors in Niger State with $66.2 \%$ of them falling within the category. The reason for the low accessibility to modern Shea butter processing technologies in the study area could be that the technologies were expensive and the cost of maintaining the equipment may be high that many processors may not be able to afford, hence, the low level of accessibility to processing technologies. It could also be that the intervention in term of equipment discussed earlier may not cover the whole state because of large numbers of processors or processor groups in the state.

Table 1: Accessibility to modern Shea butter processing technologies

\begin{tabular}{lll}
\hline $\begin{array}{l}\text { Modern processing } \\
\text { technologies }\end{array}$ & Mean & $\begin{array}{l}\text { Standard } \\
\text { deviation }\end{array}$ \\
\hline Milling Machine & 0.908 & 0.290 \\
Crusher & 0.287 & 0.453 \\
Roaster & 0.207 & 0.406 \\
Kneader & 0.096 & 0.295 \\
Cracker & 0.061 & 0.239 \\
Heated holding tank/boiler & 0.042 & 0.200 \\
Parboiling tank & 0.035 & 0.184 \\
Storage tank & 0.032 & 0.176 \\
Screw/hydraulic press & 0.022 & 0.148 \\
Vibrating screen & 0.003 & 0.056 \\
Expeller & 0.003 & 0.056 \\
Pre-cleaner & 0.003 & 0.056 \\
\hline
\end{tabular}

\section{Shea Butter Processors Outputs}

Output is the end product of a series of continuous processes. Data on Table 2 shows the distribution of the quantity of Shea butter output per annum by processors in Niger State. More than half $(58.1 \%)$ of the Shea butter processors output was $2000 \mathrm{~kg}$ and less per annum, $26 \%$ of the Shea butter processors output was between $2001-4000 \mathrm{~kg}$ per year and the remaining $15.9 \%$ of the Shea butter processors output was more than $4000 \mathrm{~kg}$ per year. The result shows that Shea butter processing output in the study area is low. The minimum annual Shea butter processing output was $288 \mathrm{~kg}$, the maximum annual Shea butter processing output 
Creative Commons User License: CC BY-NC-ND

Abstracted by: EBSCOhost, Electronic Journals Service (EJS),

Google Scholar, Journal Seek, Scientific Commons,

Food and Agricultural Organization (FAO), CABI and Scopus

http://eoi.citefactor.org/10.11226/v24i4
Journal of Agricultural Extension

Vol. 24 (4) October, 2020

ISSN(e): 24086851; ISSN(Print); 1119944X

http://journal.aesonnigeria.org

http://www.ajol.info/index.php/jae

Email: editorinchief@aesonnigeria.org

was $11,712 \mathrm{~kg}$ and the annual average Shea butter processors output was $2,303.66 \mathrm{~kg} \pm 1917.85$.

Based on the level of Shea butter processors output in Niger state, most of the processors fell under the low level of Shea butter processing output (64.8\%) with the output of between $288.00-2,303.65 \mathrm{Kg}$ per annum while the rest fall under the high level of Shea butter processing output. It is interesting to note that despite Niger State government interest in developing Shea butter processing output, most of the processors still fell under the low level category of processors output. The reason for this could be attributed to some of the constraints identified in the study such as lack of credit assistance from government and commercial banks to help the processors expand their enterprise, high cost of processing equipment that can help to increase Shea butter production and lack of working materials. The reason could also be that the state being the largest State in the country, the area covered by the interventions may not be the whole state which may have affected the Shea butter processing output adversely as revealed by the study. Similarly, because of the large numbers of processor groups in the state, the intervention may not cover all the groups could be another reason.

Table 2: Quantity of Shea butter processing output per annum.

\begin{tabular}{lrl}
\hline $\begin{array}{l}\text { Quantity of Shea butter processing } \\
\text { output/ annum (kg) }\end{array}$ & Percentage & $\begin{array}{l}\text { Mean/Standard } \\
\text { deviation }\end{array}$ \\
\hline$\leq 2000$ & 58.1 & $2,303.66 \pm 1,917.85$ \\
$2001-4000$ & 26.0 & \\
$4001-6000$ & 9.5 & \\
$6001-8000$ & 4.2 & .9 \\
$8001-10000$ & 1.9 & \\
$10001-12000$ & 0.3 &
\end{tabular}

Minimum=288, Maximum=11,712.00

\section{Constraints to Shea Butter Processing}

Table 3 reveals the constraints confronting Shea butter processing in Niger State to include lack of credit facilities ( $\bar{x}=1.78)$, high cost of processing equipment $(\bar{x}=1.72)$ and lack of government assistance in term of inputs $(\bar{x}=1.71)$ as major constraints to Shea butter processing. Lack of credit facilities in the sector could be attributed to negligence of government and investors to see Shea butter processing as a profitable business. The cost of a unit Shea butter processing plants is very high and many processors may not be able to buy the equipment. The result on government assistance shows that the processors were not getting the adequate support in term of credits and inputs from government to help the processors enhance their enterprises.

Okolo, Omoregbee and Alufohai, 2015 reported similar results of lack credit facility and lack of government assistance in term of inputs as serious constrain to Shea butter processing in North Centre zone of Nigeria. The processors needed 
Creative Commons User License: CC BY-NC-ND

Abstracted by: EBSCOhost, Electronic Journals Service (EJS),

Google Scholar, Journal Seek, Scientific Commons,

Food and Agricultural Organization (FAO), CABI and Scopus

http://eoi.citefactor.org/10.11226/v24i4
Journal of Agricultural Extension

Vol. 24 (4) October, 2020

ISSN(e): 24086851; ISSN(Print); 1119944X

http://journal.aesonnigeria.org

http://www.ajol.info/index.php/jae

Email: editorinchief@aesonnigeria.org

assistance in form of loans to buy equipment and Shea nuts to increase their level of output which are usually not available to them. This could be part of the reason for low Shea butter processing output in Niger state since the processors were not getting adequate financial assistance and inputs from the commercial banks and government agencies such as the Nigerian Export Promotion Council (NEPC) to boost Shea butter processing output in the state.

Table 3: Constraints to Shea butter processing

\begin{tabular}{lll}
\hline Constraints & Mean & $\begin{array}{l}\text { Standard } \\
\text { deviation }\end{array}$ \\
\hline Lack of credit facility & 1.78 & 0.53 \\
High cost of processing equipment & 1.72 & 0.53 \\
Lack of govt. assistance & 1.71 & 0.61 \\
Lack of modern Shea butter processing technology & 1.59 & 0.68 \\
Lack of working materials & 1.55 & 0.61 \\
Tedious method of processing & 1.53 & 0.65 \\
Felling of Shea trees & 1.49 & 0.70 \\
Scarcity of Shea nuts & 1.45 & 0.62 \\
Lack of portable water & 1.38 & 0.70 \\
Lack of market for Shea butter & 1.34 & 0.65 \\
Lack of electricity & 1.31 & 0.83 \\
High cost of maintaining equipment & 1.22 & 0.83 \\
Lack of storage facilities & 1.07 & 0.80 \\
Labour scarcity & 0.97 & 0.77
\end{tabular}

Relationship between selected Socio-economic Characteristics, Accessibility to modern Processing Technologies and Shea Butter Processing Output.

Table 4 shows the Chi-square relationship between selected socio-economic characteristics and level of Shea butter processing output. The Table reveals that level of education $\left(x^{2}=11.18, p \leq 0.05\right)$ and level of engagement of the processors $\left(x^{2}=8.71, p \leq 0.05\right)$ were significantly related to the level of Shea butter processing output. However, method of processing and sources of finance were not significantly related to level of processing output. The result on level of education and level of engagement of the processors were in agreement with the apriori expectation. The higher the educational attainment of the processors, the higher the processing output since education will allow them to have good understanding of innovations in the industry and guide them on the appropriate technologies to adopt that would translate to increased Shea butter production in the state.

Table 4 reveals that income from Shea butter $(r=0.82, p \leq 0.05)$ and accessibility to modern Shea butter processing technologies $(r=0.16, p \leq 0.05)$ were significantly related to the level of Shea butter processing output in Niger state. The higher the Shea butter processing output, the higher the income expected to 'be derived from the enterprise. Similarly, access to modern Shea butter processing technologies would enhance the adoption of the technologies and utilisation of the technologies that could translate to increased Shea butter output. As the processors utilise these 
Creative Commons User License: CC BY-NC-ND

Abstracted by: EBSCOhost, Electronic Journals Service (EJS),

Google Scholar, Journal Seek, Scientific Commons,

Food and Agricultural Organization (FAO), CABI and Scopus

http://eoi.citefactor.org/10.11226/v24i4
Journal of Agricultural Extension

Vol. 24 (4) October, 2020

ISSN(e): 24086851; ISSN(Print); 1119944X

http://journal.aesonnigeria.org

http://www.ajol.info/index.php/jae

Email: editorinchief@aesonnigeria.org

technologies because they are more accessible to them, the Shea butter processing output is expected to increase since technology is known to make difficult processing stages easier that could lead to more Shea butter processing output.

Table 4: Relationship between Socio-economic Characteristics, Accessibility to modern Processing Technologies and level of Shea butter processing output.

\begin{tabular}{lll}
\hline Variables & $\mathbf{X}^{2}$ & $\begin{array}{l}\text { r- } \\
\text { value }\end{array}$ \\
\hline $\begin{array}{l}\text { Household size } \\
\text { Unit price/Kg }\end{array}$ & 0.06 \\
$\begin{array}{l}\text { Income from Shea butter } \\
\text { Level of education }\end{array}$ & 0.07 \\
Method of production & $0.82^{* *}$ \\
$\begin{array}{l}\text { Sources of finance } \\
\text { Level of engagement }\end{array}$ & $11.18^{\star *}$ & \\
$\begin{array}{l}\text { Accessibility to modern Shea butter processing } \\
\text { technologies }\end{array}$ & 0.01 & \\
\hline${ }^{* *} P \leq 0.05$ & & \\
& & \\
\end{tabular}

\section{Factors associated with Level of Shea Butter Processing Output}

Table 5 reveals that some selected socio-economic characteristics and level of accessibility to modern Shea butter processing technology $(F=104.13, P \leq 0.05)$. Household size $(\beta=-0.065, P \leq 0.05)$, unit price of one Kilogramme of Shea butter $(\beta=-$ $0.380, P \leq 0.05)$, income from Shea butter $(\beta=0.978, P \leq 0.05)$ and accessibility to modern Shea butter processing technologies $(\beta=0.138, P \leq 0.05)$ determined level of Shea butter processing output in Niger State. However, the contribution from household size and unit price of one Kilogramme of butter were negative.

The result on income is in congruent with the report of Anigbogu, Agbasi and Okoli (2015) that a positive significant relationship existed between income and aggregate agricultural productivity (output) of farmers in Imo state. Income derived from an enterprise is expected to stimulate output. As the income of the Shea butter processors increases, the processors will respond by increasing their level of Shea butter processing output. The reason for significance of accessibility to modern Shea butter processing technologies to Shea butter production could be because the more accessible the technologies were to the processors, the more is the likelihood of the technologies being evaluated by them and possibly influencing the adoption and utilisation of the technologies. So, the more the processors had access to modern Shea butter processing technologies, the more the expected level of utilisation of the technologies which is in turn expected to translate into more Shea butter processing output in the study area.

Household size and unit price of one Kilogramme of butter had inverse relationship with level of Shea butter processing output. The result on household size was similar to a study on cocoa by Fawole and Rahji (2016) that report a negative contribution of 
Creative Commons User License: CC BY-NC-ND

Abstracted by: EBSCOhost, Electronic Journals Service (EJS),

Google Scholar, Journal Seek, Scientific Commons,

Food and Agricultural Organization (FAO), CABI and Scopus
Journal of Agricultural Extension

Vol. 24 (4) October, 2020

ISSN(e): 24086851; ISSN(Print); 1119944X

http://journal.aesonnigeria.org

http://www.ajol.info/index.php/jae

Email: editorinchief@aesonnigeria.org

family size and output. This indicates that the lower the household size, the higher the level of processing output. The reason for this could be that the more member of the household that were used, the less they actively participate because they tend to leave work for each other which may affect the level of output on the long run as compared to very few people that gives their best to achieve higher processing output.

The lower the price of one kilogramme of Shea butter, the higher the level of processing output. Contrary to prior expectation, the result indicates an inverse relationship between unit price of one Kilogramme of butter and Shea butter processing output in Niger state and statistically significant. The result disagrees with the work of Verter (2015) which shows a weak relationship between the producer price index (PPI) and crop production in Nigeria. The reason for this is not farfetched because as the price gets lower, the processors would have to increase processing output in order to get a favourable income from Shea butter processing to make up for the lower price. The most determinant of the level of Shea butter processing output was income from Shea butter (97.8\%) and accessibility to modern processing technologies (13.8\%).

\section{Table 5: Factors associated with level of Shea butter processing output}

\begin{tabular}{|c|c|c|}
\hline Variables & Beta & t-value \\
\hline Constant & & \\
\hline Household size & -0.065 & $-2.294^{\star \star}$ \\
\hline Education (formal) & -0.014 & -0.506 \\
\hline Unit price of $1 \mathrm{Kg}$ butter & -0.380 & $-12.785^{\star \star}$ \\
\hline Income from Shea butter & 0.978 & $32.257^{* *}$ \\
\hline Method of production & 0.043 & 1.599 \\
\hline Level of engagement & 0.009 & 0.315 \\
\hline Sources of finance & 0.024 & 0.903 \\
\hline Accessibility to modern processing technologies & 0.138 & $4.948^{* *}$ \\
\hline Constraint to Shea butter processing & 0.050 & 1.805 \\
\hline
\end{tabular}

\section{Conclusion and Recommendations}

The determinants of Shea butter processing output were income, household size, unit price of butter and accessibility to modern processing technologies. Processors had low level of accessibility to modern Shea butter processing technologies and most of them were processing at low level of output. Lack of credit facilities and high cost of processing equipment were identified as severe constraint. Level of education and engagement of processors, income and accessibility to modern Shea butter processing technologies were found to have a significant relationship with the level of processing output.

Financial institutions should provide soft loans to Shea butter processors to help them acquire inputs and processing equipment to improve access to modern Shea 
Creative Commons User License: CC BY-NC-ND

Abstracted by: EBSCOhost, Electronic Journals Service (EJS),

Google Scholar, Journal Seek, Scientific Commons,

Food and Agricultural Organization (FAO), CABI and Scopus
Journal of Agricultural Extension

Vol. 24 (4) October, 2020

ISSN(e): 24086851; ISSN(Print); 1119944X

http://journal.aesonnigeria.org

http://www.ajol.info/index.php/jae

Email: editorinchief@aesonnigeria.org

butter processing technologies. Similarly, Government agencies such as the Nigerian Export Promotion Council (NEPC) and the Niger State Commodity Export Promotion Council (NSCEPC) should provide Shea butter processing equipment such as milling machine, crusher, roaster and kneader to the processors to improve their accessibility to modern processing technologies that have been identified to increase Shea butter production, thereby enhancing the enterprises in Niger state.

\section{References}

Akinsokeji, O.A., S.A. Tijani, M.K. Sanusi, L. Igene and Orifah, M.O (2017). Perception of modern processing technology by Shea butter processors in Kwara State, Nigeria. Journal of Agricultural Extension. 21(1): 1-14.

Anigbogu, T. U, Agbasi, O. E and Okoli I. M (2015). Socioeconomic factors influencing Agricultural production among cooperative farmers in Anambra State, Nigeria. International Journal of Academic Research in Economics and Management Sciences. 4 (3): 54-56.

Fawole W. O and Rahji M. A. Y (2016). Determinants of Productivity among Farmers in Ondo State of Nigeria. Asian Journal of Agricultural Extension, Economics \& Sociology. 9 (4): 4.

Food and Agricultural Organization Statistic (2018). Karite (Shea nut) production in Nigeria from 1961-2018. Food and Agriculture Organization of the United Nations Statistics Division. Rome. Accessed online from faostat3.fao.org/home/E on 9th July 2018.

Nigerian Export and Promotion Council (NEPC) official website. www.nepc.gov.ng. Accessed on 20th October, 2015.

Okolo, C. C, Omoregbee, F. E and Alufohai, G. O (2015). Benefits and constraints of Shea butter production by women in Nasarawa State, Nigeria. Journal of Tropical Agriculture, Food, Environment and Extension. 14 (2): 58 - 59.

Rousseau K, Denis G and Wardell D. A (2015). Coping with the upheavals of Globalization in the Shea Value Chain: The maintenance and relevance of upstream Shea nut supply chain organization in Western Burkina Faso. World Development. 66: 414. An online material accessed from http://dx.doi.org/10.1016/j.worlddev.2014.09.004 on 4th October, 2015.

Sanusi M. K, Adeloye, F. F. and Adegebo S. A (2017). Problems confronting Shea butter industry in Nigeria. International Journal of Sustainable Agricultural Research. 4 (4): 101-112.

Sanusi, M. K and Tijani, S. A (2018). Utilisation of modern processing technologies among Shea butter processors in Niger State, Nigeria. Journal of Agricultural Extension. 22 (2): 98.

Tijani, S. A and Sanusi, M. K (2019). Level of involvement of Shea butter processors in processing activities in North-central, Nigeria. Nigerian Journal of Rural Sociology. 19 (1): 55 and 59.

Vecter, $N$ (2015). Determinants of crop productivity in Nigeria in the era of Agribusiness. Agrarian Perspectives XXIV - Global Agribusiness and Rural Economy International Scientific Conference held at Prague September 2015: 514. 